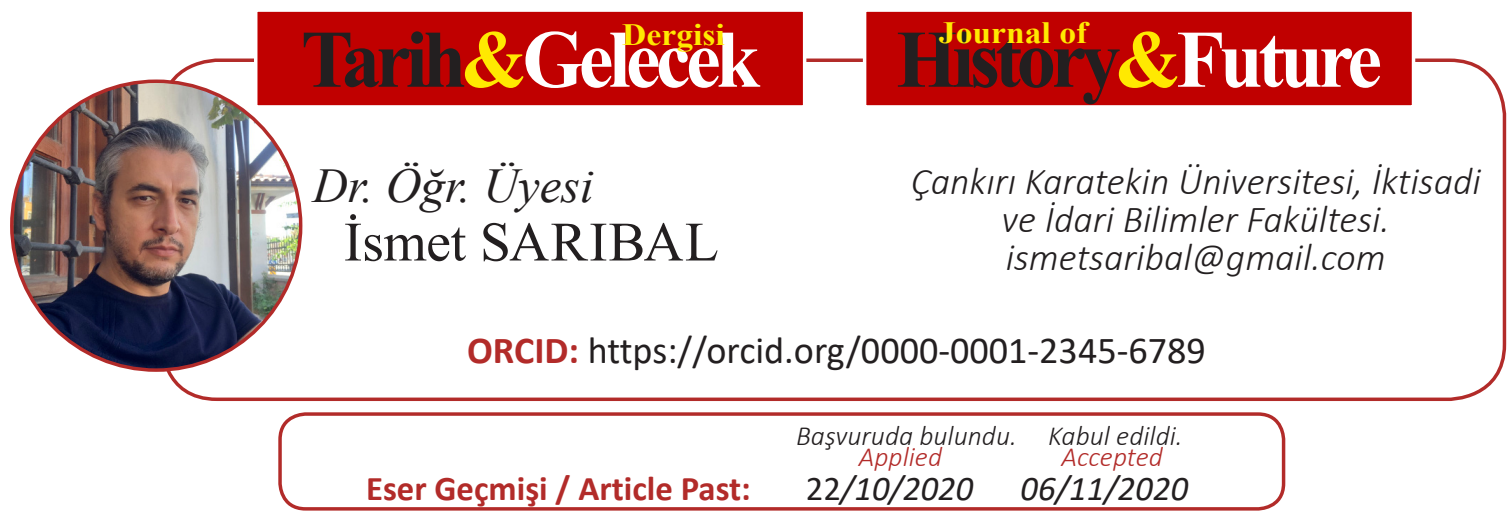

Araştırma Makalesi

DOI: http://dx.doi.org/10.21551/jhf.815095

Research Paper

Orjinal Makale / Orginal Paper

\title{
İkbalden Zevale: Sultan II. Abdülhamid'in Mâbeyn-i Hümâyûnundan Kazanlı Ahmed Nermi Bey
}

\author{
From Prosperity to Decline: Ahmed Nermi Bey of Kazan from Sultan II. \\ Abdulhamid's Mâbeyn-i Humâyûn \\ Öz
}

Ahmed Nermi Bey, Kazan'dan İstanbul'a göç etmiş bir muhacirdi. İstanbul'a göç ettikten sonra Mülkiye'ye girmiş, beş yıllık bir eğitim sürecinin ardından siyasi ilimler diplomasını alarak mezun olmuştu. Sultan II. Abdülhamid'in Mülkiye mezunlarına olan ilgisi nedeniyle mezuniyetinin ardından Mekteb-i Harbiyeye Rusça muallimi olarak atanmış, bu işe başlamasının ardından kısa bir süre sonra da Mâbeyn mütercimleri arasına dâhil edilmişti. Ahmed Nermi Bey, Sultan için yüzlerce kitap ve seyahatname çevirisi yapmış, Rusya ve Rusya Müslümanlarıyla ilgili haberlerden Sultan’1 haberdar etmek için özel çaba sarf etmiş önemli bir isimdi. Lakin Sultan II. Abdülhamid iktidardan düşünce Ahmed Nermi Bey de işinde olmuş, zor yıllar geçiren Ahmed Nermi Bey en sonunda açlıktan intihar ederek yaşamına son vermişti. Ahmed Nermi Bey’in adı bürokraside daha iyi bir konuma gelemediği için sadece yaptığ çevirilerle anılmış, hayatına dair diğer ayrıntılardan şimdiye değin söz edilmemişstir. Bu çalışmada Ahmed Nermi Bey’in Kazan'da başlayıp Anadolu'da meçhul bir yerde intiharla son bulan hayatı hakkında değerlendirmelerde bulunulacaktır.

Anahtar Kelimeler: II. Abdülhamid, Mülkiye, Mekteb-i Harbiye, Mâbeyn Mütercimliği, İntihar.

\section{Abstract}

Ahmed Nermi Bey was an immigrant from Kazan who migrated to Istanbul. After immigrating to Istanbul, he entered the Civil Service (Mülkiye) and graduated with a diploma in political sciences after a five-year education period. Due to Sultan II. Abdulhamid's interest in the graduates of the Civil Service (Mulkiye), he was appointed as a Russian teacher to the Military School (Mekteb-i Harbiye) on after his graduation, and he was included among the Mâbeyn (the palace secretariat) translators after a short time. Ahmed Nermi Bey was an important figure who translated hundreds of books and travel books for the Sultan and made special efforts to inform the Sultan about the news from Russia and Russian Muslims. However, when Sultan II. Abdulhamid fell from power, Ahmed Nermi Bey has also lost his 
job, and after many tough years, he finally ended his life by committing suicide from hunger. Ahmed Nermi Bey's name has only been mentioned with his translations since he could not reach a higher position in the bureaucracy, and other details of his life have not been touched upon until now. In this study, evaluations will be made about the life of Ahmed Nermi Bey, which started in Kazan and ended with suicide in an unknown place in Anatolia.

Keywords: Sultan II. Abdulhamid, Civil Service (Mulkiye), Military School (Mekteb-i Harbiye), Mâbeyn (the palace secretariat) Translators, Suicide.

\section{Giriş}

hmed Nermi Bey 1861 yılında Moskova'da doğmuştu. Kazan Tatarlarındandı.
Babası Kazan ulemasından Nureddin Efendi’ydi. Ahmed Nermi Bey
ilköğrenimini kardeşi Ali Nureddin Bey’le birlikte pederinin nezaretinde
tamamlamış, bu süreçte ayrıca muallim-i mahsustan ders alarak Rusçayı
öğrenmişti. Ali Nureddin Bey’in tercüme-i hâlinden anlaşıldığına göre iki kardeş eğitimlerini daha sonra Kazan medreselerinde mesâ'il-i diniyye, sarf, nahv, mantık, kıraat dersleri tahsil ederek devam ettirmişti ${ }^{1}$.

Balkanlar üzerindeki emelleri Kırım Savaşı'nda aldığı mağlubiyetle kesintiye uğrayan Rusya, istikametini Ural madenlerine, Türkistan pamuğuna ve Bakü petrolüne dikmiş², 1774 Küçük Kaynarca Antlaşması'ndan itibaren bölge Müslümanları üzerinde uyguladığı baskıyı daha da arttırmışıı. Bu baskı sonucunda milyonlarca Kırımlı ve Kafkasyalı zorunlu olarak Osmanlı Devleti'ne göç etmiş, bu göç sürecine özellikle dini baskılar ve Ruslaştırma siyasetinin yarattı̆̆ huzursuzluk nedeniyle İdil-Ural bölgesinde yaşayan Kazan Tatarları da dâhil olmuştu³. Ahmed Nermi Bey ve ailesi de - her ne kadar göç tarihlerini kesin olarak tespit edemesek de - bu göç sürecinde 1870'li yılların başında Rusya'dan zorunlu olarak İstanbul'a göç etmişti.

Osmanlı Devleti, Kırım ve Kafkas kitle göçüyle gelen muhacirlere karşılıksız arazi vermiş, ziraat yapmaları için alet-edevat, tohum gibi malzemeler dağıtmış, muhacirlerin bir an evvel üretici pozisyona geçmelerini temin etmeye çalışııstı. Pek tabii gelen muhacirlerin tamamı çiftçi değildi. O nedenle tüccar, esnaf ve sair zanaat erbabı ile din adamları şehirlerde iskân edilmiş, bu gibi kimselere aynî ve nakdî destek verilmişti. Özellikle din adamlarına imkânlar çerçevesinde maaş bağlanmış, mesleklerini icra etmelerinde kolaylık sağlanmıştı ${ }^{4}$. Bu nedenledir ki Nureddin Efendi göç sürecinin envai sıkıntısından masun kalarak çocukları Ahmed Nermi Bey'i Mekteb-i Mülkiyeye, diğer oğlu Ali Nureddin Bey’i de Mekteb-i Tıbbiyeye gönderme şansı bulmuştus.

1 BOA, DH.SAID.d, Defter No: 47, s. 249; BOA, DH.SAID.d, Defter No: 71, s. 63.

2 Jacques Pirenne, Büyük Dünya Tarihi, III, çev. Nihat Önol, Meydan Gazetesi Yayınları, İstanbul 1972, s. 1296

3 Arzu Kılınç Ocaklı, "XIX. Yüzyılda İdil-Ural Bölgesinden Anadolu’ya Göçler”, Türkler, XIII, Yeni Türkiye Yayınları, Ankara 2002, ss. 896-906.

4 Kırım ve Kafkas göçleri hakkında bk. Abdullah Saydam, Kırım ve Kafkasya Göçleri (1856-1876), Türk Tarih Kurumu Yayınları, Ankara 1997.

$5 \quad$ BOA, DH.SAID.d, Defter No: 47, s. 249; BOA, DH.SAID.d, Defter No: 71, s. 63 
Ahmed Nermi Bey üç yılı idadi, iki yılı âlî olmak üzere beş yıllık bir eğitim sürecinin sonunda 18 Temmuz 1886 tarihinde karîb-i âlâ (iyi) derecesiyle ulûm-1 siyasiye diplomasını almaya hak kazanmıştı. Nermi Bey bu eğitimi sırasında hem konuşup hem Türkçeye tercüme edecek derecede Fransızcayı da öğrenmiştíi . Mekteb-i Mülkiyeye devrin padişahı Sultan II. Abdülhamid özel bir önem vermekteydi. Hatta bu okulu birincilikle bitirenler doğrudan Mâbeyne kâtip olarak atanmaktayd ${ }^{7}$. Bu sebebe mebni çok iyi bir dereceyle mezun olmasa da Ahmed Nermi Bey'in Mülkiye mezuniyeti talihini değiştirmişti.

\section{Mekteb-i Harbiye Rusça Muallimliği}

Ahmed Nermi Bey'in mezun olduğu dönemde Osmanlı ordusu kapsamlı bir yeniden yapılanma sürecine girmişti. Sultan II. Abdülhamid, 93 Harbi sonrası etkinliğini tamamen yitiren orduyu yeniden canlandırmak için 1866'da Avusturya'yı, 1871'de Fransa'yı yenerek Avrupa'nın göbeğinde "politik bir hegemonya" oluşturan Prusya'dan ${ }^{8}$ askeri uzmanlar getirtmeye karar vermiş̧i. Yapılan görüşmeler sonucunda 4 subaydan oluşan ilk Alman askeri heyeti Albay Kahler başkanlığında 11 Nisan 1882'de İstanbul'a geldi. Osmanlı Devleti ayrıca askeri okulların eğitimöğretim faaliyetlerini denetlemek üzere bir uzman daha talep etmiş, bu talep üzerine Binbaş1 Colmar von der Goltz 18 Haziran 1883'te İstanbul'a gönderilmişti. Askeri Mektepler Nazırı Zeki Paşa'nın yardımcısı olarak göreve başlayan Goltz, kısa süre sonra Askeri Mektepler Müfettişi oldu. Goltz, Kahler'in vefat etmesi üzerine 1886'da Alman askeri heyetinin başına geçti. Bu tarihten sonra Goltz'un Osmanlı ordusu üzerindeki etkinliği daha da $\operatorname{artt1}^{9}$. Goltz, Harbiye'de önemli reformlar yapmıştı. Bu reformlardan biri de Harbiye Mektebi müfredatına Almanca ve Rusça derslerinin eklenmesiydi ${ }^{10}$. İşte Ahmed Nermi Bey, bu karar çerçevesinde, Mülkiye mezuniyeti ve de çocukluk döneminde Rusça eğitim almış olmasının da katkısıyla 28 Ekim 1886'da Harbiye Mektebine Sultan'ın iradesiyle Rusça muallimi olarak atand $1^{11}$.

Mekteb-i Harbiyede görevlendirilecek muallim ve muavinler esasen zabitler arasından seçilmekteydi. İlk önceleri okul yıllarında başarı gösteren öğrenciler hocalar tarafından takip edilir, bu başarılı öğrencilerin akademik ve ahlaki gelişimleri için ayrıca mesai harcanır ve nihayet mezun olduktan sonra bu zabitlerden istekli olanlara muallimlik ve muavinlik görevleri tevdi edilirdi. 1877 yılında, bu seçim ve tayin sisteminde yaşanan bazı suiistimalleri ortadan kaldırmak ve kalıcı bir düzen oluşturmak amacıyla mektepte muallimliğe ve muavinliğe talip olan zabitler için Mekâtib-i Askeriye Nezaretince yapılacak imtihandan başarılı olma şartı getirilmişti ${ }^{12}$. Pek tabii dil öğretimi doğrudan askerlikle ilgili bir meslek olmadığı için Sultan'ın iradesiyle dişarıdan muallim tayin edildiği vakiydi. Mekteb-i Harbiyede Goltz’un yaptığı değişikliğe değin Avrupa dillerinden

$6 \quad$ BOA, DH.SAID.d, Defter No: 47, s. 249.

7 Abdülhamit Kırmızı, "Meşrutiyette İstibdat Kadroları: 1908 İhtilali’nin Bürokraside Tasfiye ve İkame Kabiliyeti”, 100. Yllında Jöntürk Devrimi, ed. Sina Akşin-Sarp Balcı-Barış Ünlü, Türkiye İş Bankası Kültür Yayınları, İstanbul 2010, s. 345.

8 Pirenne, a.g.e., 1359.

9 Jehuda L. Wallach, Bir Askeri Yardımın Anatomisi, çev. Fahri Çeliker, Genelkurmay Başkanlığı Yayınları, Ankara 1977, s. 25-45.

10 Kazım Karabekir, Türkiye'de ve Türk Ordusunda Almanlar, yay. haz. Orhan Hülagü-Ömer Hakan Özalp, Emre Yayınlar1, İstanbul 2001, s. 205-235.

11 BOA, DH.SAID.d, Defter No: 47, s. 249.

12 Mehmed Esad, Mir'ât-l Mekteb-i Harbiye, Artin Asaduryan Matbaas1, İstanbul H 1310, s. 90-92. 
yalnızca Fransızca eğitimi verilmekteydi. Önceleri yabancı hocalar tarafından verilen Fransızca dersleri zamanla mektepten mezun olan subaylardan tarafından verilmeye başlanmıştı. Rusça dersi için de benzer bir durum söz konusuydu. Ahmed Nermi Bey haricinde ilerleyen yıllarda Rusça bilen/ öğrenen subaylar arasından yine Rusça muallimleri tayin edilmişti. Hâsılı Harbiye Mektebinde muallim olarak zabitlerin görevlendirilmesi hususunda bir eğilim vardı. Hatta bu eğilim dolayısıyla işe başlamasından yaklaşı 4 ay sonra Ahmed Nermi Bey'in mülkiye sınıfından askeri sınıfa geçirilmesi gündeme gelmiş, Ahmed Nermi Bey bu teklifi kabul etmemişti. Seraskerlik makamı Nermi Bey'in askeri bir rütbeye haiz olmadan görev yapmasında sakınca olmadığını Mekâtib-i Askeriye Nezaretine bildirince Ahmed Nermi Bey'in uhdesine "rütbe-i sâlise" verilerek görevine sivil rütbeyle devam etmesine müsaade edilmişti ${ }^{13}$.

Ahmed Nermi Bey'in Harbiyedeki muallimlik vazifesiyle ilgili bilgilerimiz kısıtlıdır. Bununla birlikte Ziya Yergök'ün "Harbiyeden Dersim'e" adıyla yayımlanan anıları Nermi Bey hakkında bazı bilgiler vermektedir. Yergök, Nermi Bey'in Tatar olduğunu vurgulayarak son derece yumuşak huylu olduğunu ifade etmekte ve bu nedenle kendisinden bir öğrenci olarak yararlanamadığını belirtmektedir. Yine Nermi Bey'in yaşlı olduğunu ve dersleri isteksiz bir şekilde anlattığını ifade etmektedir. Hatta bu nedenle Nermi Bey’in muavini Metot Hüsnü Bey’den öğrendikleri çoğu şeyi kurmay sınıfların dersine giren Ahmed Nermi Bey'den ders aldıkları dönemde unuttuklarını dile getirmektedir ${ }^{14}$.

Ahmed Nermi Efendi'yi şahsen tanıyan Nahid Sırrı Örik'in Ahmed Nermi Bey'in kişiliğiyle ilgili "Hatıralar ve Portreler" başlığıyla kaleme aldığı değerlendirmeleri Yergök'ün değerlendirmelerini destekler mahiyettedir. Örik'in babası Mâbeyn mütercimlerinden Hasan Sırrı Bey'dir ${ }^{15}$. Ahmed Nermi Bey, Hasan Sırrı Bey'in maiyetinde çalışmışıtır. Bu tanışıklıktan mütevellit Örik, Ahmed Nermi Bey'in hayatıyla ilgili kaleme aldığı notlarında Nermi Bey'in kişiliğigile ilgili şunları yazmıştır: Nermi Efendi, babamın arkadaşları arasında en mütevazılardan biriydi. Ama bu tevazu kendisinin maiyetinde oluşundan, ondan bir lütuf ve inayet bekleyişinden değil fitraten iddiası, hayli de plsırık oluşundand ${ }^{16}$.

Örik' in kaleme aldığı satırlardan Ahmed Nermi Bey'in - esasen biröğretmende olması gereken - etkileyiciliğinin olmadığı da anlaşılmaktadır. Hatta Örik, Nermi Bey'in karizma yoksunluğundan mütevellit bekâr kaldığını düşünmektedir. Örik'in bu husustaki değerlendirmeleri şu şekildedir: Harbiye Mektebinde Rusça muallimiydi. Yani o zamanın altın parasıyla eline ayda şüphe yok ki kirk elli lira geçiyordu. Akran ve emsali gibi o da konak yavrusu bir evde haremiyle yaşayabilir hatta bu haremden ayrıca bir odalık edinebilir, yarının düşünmezse borç harç etmeksizin at, araba sahibi de olabilirdi. Ama aslen Kazanlı olup babam gibi Mülkiye mezunu olan Nermi Efendi'nin müteaddit haremleri ve odalıklarl değil tek bir karısı dahi yoktu. Uzun seneler önce teyze-zâdem İnci (?) Hanım henüz gelin olmak şöyle dursun erkekten bile kaçmadiğ sırada kendisini bizim evde görüp beğenerek Allah'ın emriyle almak istemiş fakat gösterişsiz, zaylf, boysuz, yassı çehreli ve pos biyıkl, pek kıyafet düşkünü, oldukça da yaşlı olduğu gibi nasıl bir aileden geldiği de meçhul

13 BOA, İ. DH, 1019/80358, 14 Cemaziyelevvel 1304 [8 Şubat 1887].

14 Ziya Yergök, Tuğgeneral Ziya Yergök'ün Anıları, Harbiyeden Dersime (1890-1914), yay. haz. Sami Önal, Remzi Kitabevi, İstanbul 2006, s. 76-99.

15 Hasan Sırrı Bey'in hayatı ve eserleri hakkında bk. Halil Cin, "Hasan Sırrı Örikağasızâde”, Türk Edebiyatı Isimler Sözlüğü, "http://teis.yesevi.edu.tr/ madde-detay/hasan-sirri-orikagasizade."

16 Taha Toros Arşivi, Dosya No:34, "http://earsiv.sehir.edu.tr:8080/xmlui/ handle/ 11498/38691.” 
bulunduğu için bu arzu derhal reddedilmiş, o da bundan sonra galiba bir evlenme hevesine düşmemiştili ${ }^{17}$.

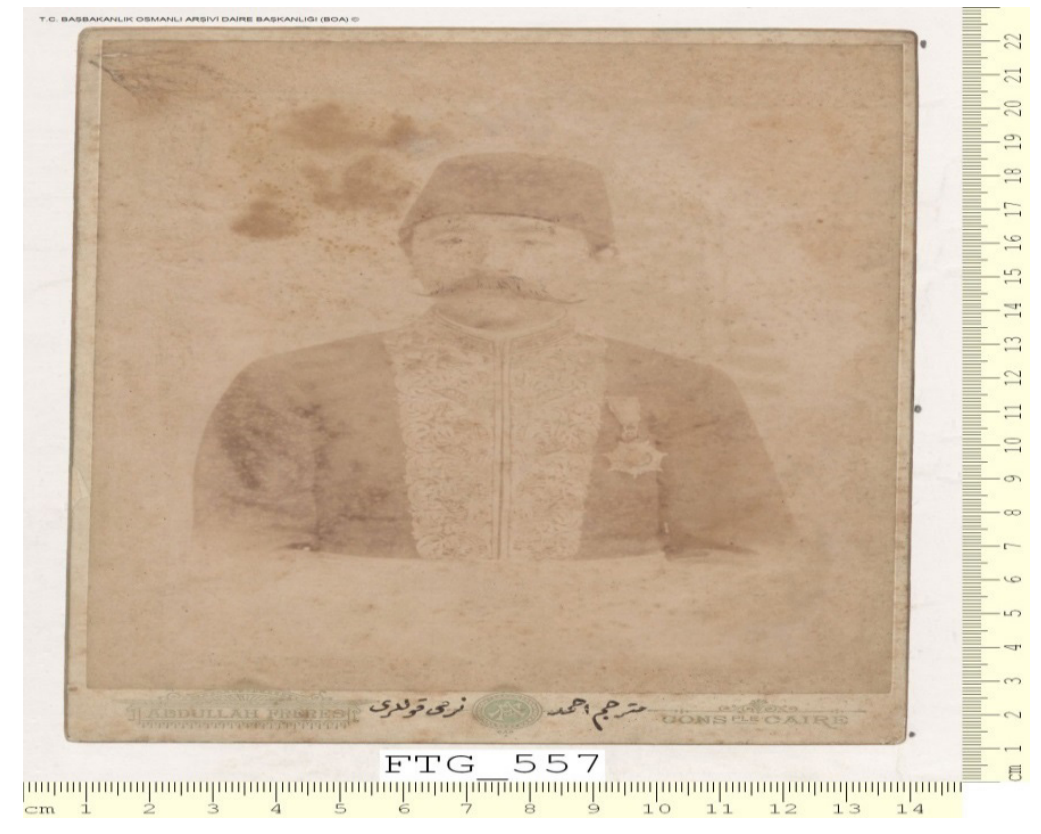

BOA, FTG.f, 557, Tarihsiz Fotoğraf.

Aslında Ahmed Nermi Bey'in derslerdeki isteksizliği veyahut kendini derse veremeyişi sadece kişiliği ve karizmasıyla ilgili hususlara müstenit değildi. Çünkü Ahmed Nermi Bey Mekteb-i Harbiyeye tayinin ardından kısa bir süre sonra 13 Aralık 1886 tarihinde muallimlik maaşına ek bin kuruş maaşla Mâbeyn mütercimliğine atanmış ${ }^{18}$, yoğun bir mesai sürecine başlamıştı.

\section{Mâbeyn Mütercimliği}

Mâbeyn mütercimliği, II. Abdülhamid döneminde ihdas edilen "Mâbeyn-i Hümâyûn Tahrirât-1 Ecnebiye Kitabeti”ne bağlı bir tercüme birimiydi. Bu birimin ne zaman kurulduğu kesin olarak bilinmemektedir fakat Babıali Tercüme Odası memurlarından Aristidi Efendi'nin Kasım 1879'da Mâbeyn mütercimliğine 3.000 kuruş maaşla atanmasından bu memuriyetin Kasım 1879 'dan evvel kurulduğu anlaşılmaktadır ${ }^{19}$.

Sultan II. Abdülhamid, basın-yayın yoluyla kendisi hakkında oluşturulmak istenen kötü imajı kırmak için sefirleri ve Mâbeynine aldığı mütercimleri kullanmıştı. Sefirler bulundukları ülkede Sultan hakkında çıkan gazete yazılarını takip eden âdeta birer ajana dönüşmüştü. Sefirler ayrıca tiyatro oyunların takip etmiş, bunlar hakkında raporlar düzenlemiş hatta Osmanlı aleyhine sahneler içeren oyunların kaldırılması için girişimlerde bulunmuştu. Mütercimler de sefirler kadar zor bir görev icra etmişlerdi. Mütercimlerin görevi, Osmanlı aleyhine yazılmış kitapları tespit etmek ve bunların ülkeye girmesini engellemekti. Mütercimler ayrıca Sultan'ın okumaktan ve dinlemekten hoşlandığı romanları - özellikle de polisiye olanları - ve seyahatnameleri - özellikle de Osmanlı ülkesini ve sultanını küçültücü ifadeler içerenleri - de Türkçeye tercüme etmekle

17 Taha Toros Arşivi, Dosya No:34, "http://earsiv.sehir.edu.tr:8080/xmlui/ handle/ 11498/38691."

18 BOA, DH.SAID.d, Defter No: 47, s. 249.

19 Sezai Balcı, Babıâli Tercüme Odası, Libra Yayınları, İstanbul 2018, s. 232. 
görevliydiler ${ }^{20}$.

Ahmed Nermi Bey'in Mâbeyn mütercimleri içerisinde özel bir konuma sahip olduğunu söylemek mümkündür. Bazı yazarlar Nermi Bey'in Sultan II. Abdülhamid'in Rusya ahvali hakkında müstesna bir mütercimi olduğunu, genel olarak Rusya ve özel olarak Rusya Müslümanlarıly ilgili tercümeleriyle Ahmed Nermi Efendi'nin doğduğu topraklarla, soydaşlarıyla Sultan'1 alakadar etmek için inisiyatif kullandığ kanaatindedir ${ }^{21}$. Bu önemli hususun yanı sıra Nermi Bey'in Sultan için, tespit edilebildiği kadarıyla, iki yüze yakın seyahatname, yüze yakın roman çevirisi yaptığı tespit edilmiştir ${ }^{22}$.

Bütün bu çabalarına rağmen Ahmed Nermi Bey Mülkiye'den Mâbeyne geçen çoğu Mülkiyeli gibi valiliğe veyahut bürokraside daha üst bir göreve geçememişti. Aslında Nermi Bey Babıali'de işlerin nasıl yürüdüğünü çok iyi öğrenmiş̧i. Bu bakımdan fırsatını bulduğunda şansını denemekten geri durmamıştı. Mesela Ahmed Nermi Bey "Rus Misyonerleri Cemiyeti" tarafindan hazırlanan 17 ciltlik, içerisinde Osmanlı Devleti aleyhine siyasi ve dini birtakım uygunsuz ifadeler barındıran kitabın 13 cildini tek başına çevirmiş, Mâbeyn kâtiplerinden Hakkı Bey de bu çeviriyi kayıt altına almıştı. Nermi Bey çeviriyi tamamladıktan sonra yazdığı bir arzuhalle kendisinin pozisyonunda olan diğer arkadaşlarının bir şekilde taltif edilmesine karşın bu gayretine rağmen takdir edilmediğinden dert yanmış, Hakkı Bey'le birlikte rütbelerinin birer derece arttırılmasını talep etmişti ${ }^{23}$. Nermi Bey mezkûr arzuhali yazmadan birkaç gün evvel Sultan'a methiyelerle dolu bir yeni yıl tebriki göndermeyi de ihmal etmemişti ${ }^{24}$. Nihayet Nermi Bey'in bu talebi biraz geç de olsa karşı11k bulmuş, padişah iradesiyle rütbesi bir derece yükseltilmiştíi ${ }^{25}$.

Pek tabii Nermi Bey'in kariyerindeki bu tarz her girişimin başarıyla sonuçlandığ söylenemez. Nitekim Nermi Bey "Encümeni Teftiş ve Muayene Komisyonu" azalarından Maliye Nazırının dayısı Ali Efendi'nin vefatı üzerine bir dilekçe kaleme almış ve on beş seneden beri kendisine sadakatle hizmet etmesinin mükâfatı olarak Sultan'dan bu azalığın memuriyetine ilave edilmesini istemişti ${ }^{26}$. Lakin her ne kadar memuriyetiyle doğrudan alakalı olsa da bu azalık görevi kendisine tevdi edilmemişti ${ }^{27}$. Arşiv kayitlarına müracaat edildiğinde Nermi Bey'in bu başarısız girişimden sonra kendi arzusuyla bir göreve talip olmadığ görülecektir. Bu da Nermi Bey'in Örik'in teyze kızına talip olup reddedilince bir daha hiç evlenme hevesine düşmemesine benzer bir durumu iş hususunda yaşadığını akla getirmektedir. Anlaşılan o ki Nermi Bey bu hadiseden sonra kendisini tamamen Sultan'ın tercüme işlerine vermiş̧ir.

Ahmed Nermi Bey her ne kadar bürokraside bulunduğu konumdan daha üst bir mevkiye gelemediyse de hizmetlerinden ötürü en yüksek mülki rütbelerden biri olan ûlâ evveli rütbesine

20 İbrahim Şirin, “Gazete, Kitap, Tiyatro Karşısında İmajını Korumaya Çalışan Sultan ve Maiyeti: Sultan II. Abdülhamid ve Ahmed Nermi”, Uluslararası Kıbrıs Üniversitesi Folklor/Edebiyat Dergisi, 17 (66), 2011, s. 40-44.

21 Saime Selenga Gökgöz, “II. Abdülhamid'e Takdim Edilen Bir Arz-1 Hâl: 'Kugu Sigorta' ve İslam Halifesi”, Kebikeç, (26), 2008, s. 66.

22 Şirin, a.g.m., s. 46-53.

23 BOA, Y. PRK. AZJ, 22/66, 17 Muharrem 1310 [11 Ağustos 1892]

24 BOA, Y. PRK. AZJ, 22/53, 1 Muharrem 1310 [26 Temmuz 1892]

25 BOA, İ. TAL, 17 / 26, 14 Ramazan 1310 [1 Nisan 1893]

26 BOA, Y. PRK. AZJ, 26/77, 29 Zilhicce 1310 [14 Temmuz 1893]

27 BOA, DH.SAID.d, Defter No: 47, s. 249. 
kadar terfi etmişti. Bu rütbeye sahip olanlar ricalden sayılmaktaydı. Askeri rütbelerden ferikliğe muadildi. Bu rütbe sahiplerine paşa denilmez, daha önceki durumlarına göre "bey" yahut "efendi" denilirdi. Resmi günlerde rütbelerine özel sırmalı bir elbise giyerler, kılıç kuşanırlar ve saadetlü unvanını kullanırlard ${ }^{28}$.

Ahmed Nermi Bey'in adı Sultan II. Abdülhamid'in mâbeyninde çalıştığı dönemde kamuoyu tarafından çevirileriyle değil 1897 Osmanl1-Yunan Harbi yıllarında üstlendiği bir görevle duyulmuştu. Bu harp sırasında yaralanan Osmanlı askerleri için Rusya kralı ve validesi tarafından seyyar bir hastane gönderilmiş, Nermi Bey de bu çerçevede İstanbul'a gelecek olan Rus Kızılhaç personelinin mihmandarlığına görevlendirilmişti ${ }^{29}$.

Ahmed Nermi Bey bu görevde gösterdiği başarısından dolayı 19 Aralık 1897 tarihinde, 1897 Osmanl1-Yunan Harbi için ihdas edilmiş olan "Yunan Muharebe Madalyası"na layık görülmüştü. Nermi Bey'e ayrıca Rusya Devleti tarafından da ikinci rütbeden "Saint Stanislau" nişanı verilmiş, 17 Mart 1898 'de Ahmed Nermi Bey'in bu nişanı takmasına müsaade edilmişti. Ahmed Nermi Bey'in ayrıca ikinci rütbeden Mecidî nişanı da vard ${ }^{30}$.

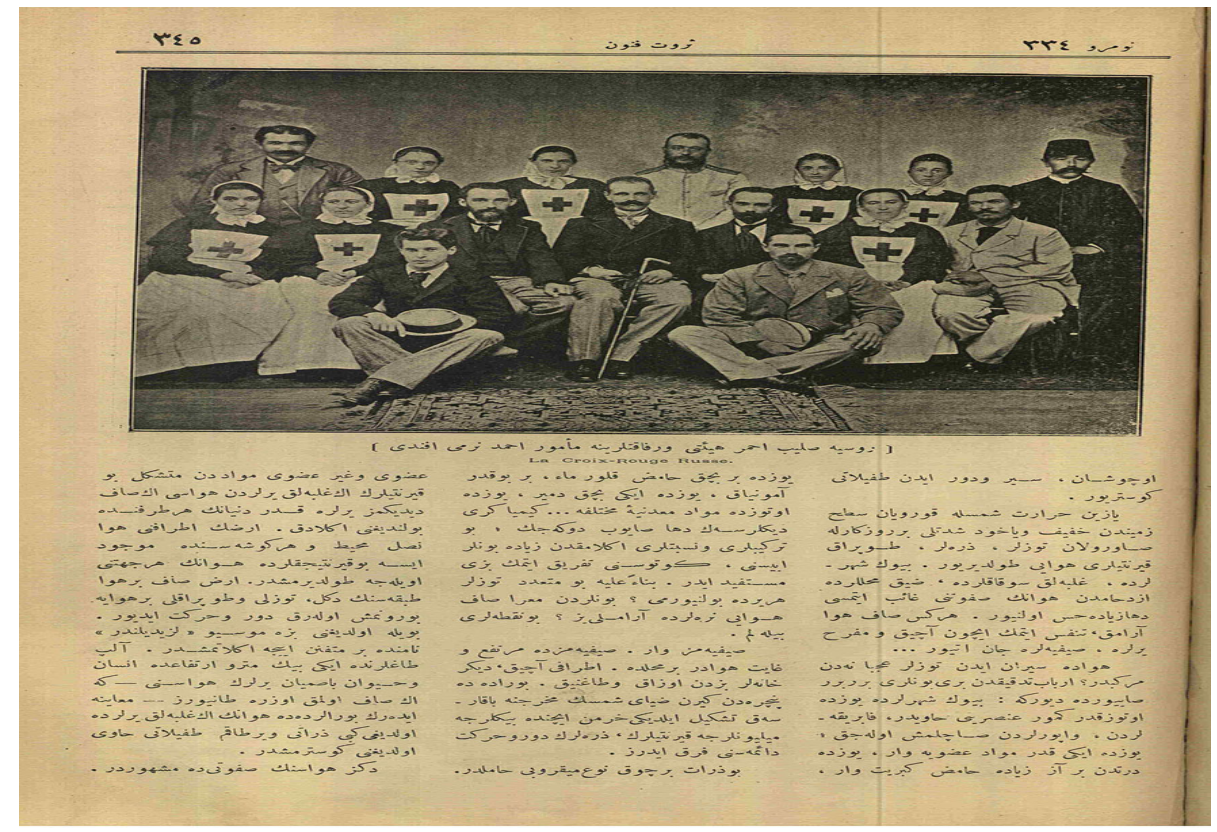

Rusya Salîb-i Ahmer Heyeti ve refakatlerine memur Ahmed Nermi Efendi ${ }^{31}$.

Ahmed Nermi Bey, Sultan II. Abdülhamid'in iktidardan indirilişine kadar Mâbeyn mütercimliğine ve Harbiye'deki muallimlik vazifesine devam etmişti. Bu süreçte daha önce zikredildiği üzere neredeyse bir külliyat olarak nitelendirilebilecek çevirilerine devam edip tespit edebildiğimiz kadarıyla başkaca bir görev almadan mütercimlik kariyerini ilerletmişti. Ancak Sultan II. Abdülhamid'in tahttan indirilmesi Ahmed Nermi Efendi için kötü günlerin başlangıcı

28 Mehmet Zeki Pakalın, Osmanlı Tarih Deyimleri ve Terimleri Sözlüğü, III, Milli Eğitim Basımevi, İstanbul 1972, s. 542.

29 BOA, HR. TH, 193/90, 6 Mayıs 1313 [18 Mayıs 1897]

30 BOA, DH.SAID.d, Defter No: 47, s. 249.

31 http://www.servetifunundergisi.com/rusya-salib-i-ahmer-heyeti-refakatlerine-memur-ahmetnermi-efendi/. 
oldu.

\section{1909 Tensikat Kanunu ve Ahmed Nermi Bey}

İttihat ve Terakki Cemiyeti, 24 Temmuz 1908'den itibaren bürokraside yaklaş1k bir yıl süren plansız bir tasfiye girişimine başlamıştı. Her ne kadar başta padişah olmak üzere devlet erkânına ve memurlara Kanûn-1 Esâsiye bağl1lık yemini ettirilmiş olsa da İttihatçılar "devr-i sâbık" mensuplarına şüpheyle bakmaktaydı. Bu nedenle kimi zaman ahalinin, kimi zaman İttihat ve Terakki Cemiyeti merkezinin veyahut da mahalli cemiyet şubelerinin baskısıyla bir tasfiye süreci başlatılmıştı. 31 Mart Vakasının (13 Nisan 1909) ardından bu keyfi tasfiyelerden vazgeçilip bürokraside planlı bir tensikat yapılmasına karar verilmiş, bunun için İstanbul' da bazı komisyonlar kurulmuştu. Tensikat için gerekli hukukî zeminin hazırlanması aylar almış, nihayet yüzlerce memuru kadro dışı bırakan tensikata 1909 yazında başlanabilmiştit ${ }^{32}$.

Ahmed Nermi Bey mezkûr tensikattan evvel, 29 Nisan 1909'da, kadrosu lağvedilince saraydaki mütercimlik vazifesinden ayrılmış, hemen akabinde ise Harbiye Mektebindeki muallimlik görevinden azledilmişti. Bu azilden yaklaşık 4 ay sonra 28 Ağustos 1909 tarihinde toplanan “Mülkiye Tekaüd Sandığ1 Heyet-i Umûmiyesi”nin kararıyla Nermi Bey’e emeklilik yaşını doldurmadığı için 1166 kuruş mazuliyet maaşı bağlanmış hatta bu işlem Tanin gazetesinde ilan edilmişti ${ }^{33}$.

Ahmed Nermi Bey mazûlin zümresine dâhil edildikten sonra bazıları gibi haksızlığa uğradığı iddiasıyla yüksek makamlara başvurup memuriyete iadesini istememiş, daha da önemlisi Kırmızı'nın ifadesiyle "yeni devre uyan enkâz-1 istibdat” zümresine dâhil olmamış yani makam ve mevki elde etmek için Sultan II. Abdülhamid'in en yakınında bulunanlardan birisiyken bir anda onun en büyük düşmanı hâline dönüşmemişti. Elbette II. Meşrutiyet Dönemi'nde görev verilen devr-i sâbık adamlarının hepsi saf değiştirmiş, ikiyüzlü kişilerden ibaret değildi. İttihat ve Terakki Cemiyeti, devr-i sâbıkın devlet adamlarının bir kısmına çeşitli görevler verip onların tecrübelerinden yararlanmışt1 ${ }^{34}$.

Nermi Bey'in bu yıllardaki vaziyetini yakinen bilen Örik, Nermi Bey'in bu dönemdeki tutumuyla ilgili şu değerlendirmeleri yapmıştı: Birinci Cihan Harbi'ne kadar bize en az ayda bir kere cuma günleri gelir fakat bir misafirin değil hatta beş on misafirin sofraya alınmasının mesâ'il teşkil etmediği o bolluk ve refah günlerinde bile yemek vaktinden sonra gelmekte itina gösterirdi. Saygılı, müstağni ve pek mütevazı olmasına rağmen çok vakarlıydı. Nitekim 25 (?) Temmuz İnklabını müteakip Sultan Hamid tahttan indirilmeden önce saraydaki mütercim teşkilatına son verildiği, Harbiye Mektebindeki Rusça hocalı̆̆ da bilmiyorum hangi sebebe mebni galiba Fenârîlerden Ahmed Saib Bey isimli keza Rusya'dan gelme bir politikacıya yer açmak üzere elinden alındiğ hâlde ne Mâbeyn ve mektep arkadaşı olup iki sene kadar devletin en yüksek makamını sadareti işgal eden Hakk Paşa'dan ve ne de on iki sene müddetle bu müddet içinde imparatorluğun gümrükleri İşkodra'dan başlayıp Hadide'ye kadar yayıldığı sırada Rusûmât Umûm Müdürlügüünü işgal etmiş olan babamdan da ağzını açıp bir hizmet ve vazife istememiş hatta hâlinden şikâyet edip en küçük

32 Kırmızı, a.g.m. , s. 339. Söz konusu tensikatla ilgili daha geniş malumat için bk. Asaf Özkan, II. Meşrutiyet'ten Cumhuriyete Askeri ve Mülki Bürokraside Tasfiyeler, Askeri ve Mülki Heyet-i Mahsusalar, Atatürk Araştırma Merkezi Yayınları, Ankara 2014.

33 Tanin, S. 354, s. 3, 11 Şaban 1327 [28 Ağustos 1909].

34 Kırmız1, a.g.m., s. 345-347. 


\section{bir imada bulunmamışt1 ${ }^{35}$.}

Aslında Örik'in Nermi Bey'in imkânı olduğu hâlde başta kendi babası olmak üzere tanıdıkları vasıtasıyla yeniden memuriyete girmek istemeyişini erdemli bir tutum olarak görmesi ve bu hususun üzerinde özellikle durması tesadüf değildir. Örik, bu durumdan o kadar rahatsız olmuştur ki "Abdülhamid Düşerken" adlı romanında bu hususu konu etmiş ve devlet adamlarının bu tutumunu ironik bir şekilde eleştirmişti. Şöyle ki, Örik'in romanında Sultan II. Abdülhamid döneminde valilik, nazırlık gibi önemli görevlerde bulunan Mehmed Şehabettin Paşa adında bir karakter vardır. Paşa, ihtilal sırasında seksenli yaşlarındadır ve yeni döneme ayak uydurmanın yollarını aramaktadır. İttihat ve Terakki Cemiyeti mensuplarından Binbaşı Şefik Bey, Paşa'nın kızı Nimet Hanım'a talip olur. Şefik Bey'in mebus seçilmesi muhtemeldir. Paşa, kızını vermek için Şefik Bey'den kendisine yeni oluşacak Âyân Heyeti'nde bir mevki temin etmesini ve yeni yönetim nazarındaki şüpheli kişi imajını düzeltmesini şart koşar. Şefik Bey evlenmek için Paşa'nın sadrazamlığı için bile çalışmaya hazırdır. Sonunda Şefik Bey mebus seçilir, Şehabettin Paşa da Âyân Heyetine dâhil olur ${ }^{36}$.

\section{Ahmed Nermi Bey'in Zor Yılları ve İntiharı}

Ahmed Nermi Bey her ne kadar yeni dönemde iktidarı elinde bulunduranlardan iş talep etmeyip Örik'e göre erdemli bir duruş sergilediyse de bu duruşun bedelini ağır bir şekilde ödemişti. Nermi Bey'in bu zor yıllarında Örik ve ailesi ona destek olmaya çalışmış, Örik bu sayede Nermi Bey'in şahsiyeti ve yaşadığı sıkıntılarla ilgili hususları etraflıca müşahede etme şansı bulmuştu.

Örik'in dikkati çeken ilk husus Nermi Bey'in birkaç dil bilen mütercimden öte kültürlü bir zat oluşu ve ruhunda barındırdığı muhacir hüznüydü. Örik'in bu husustaki değerlendirmeleri şöyledir: Hâlbuki bütün gösterişsizliğine rağmen irfanlı bir adamdı hatta babam kendisini gümrüğge ait istimbotlardan biriyle Karadeniz'e çıkarıp Kilyos'a götürmüştü de belki Kazan'dan muhacir geldiği çok eski günlerden beri görmediği bu Karadeniz'e çıkıştan büyük bir haz duyarak boğazın ağzındaki Rumeli fenerinde mola verdikten sonra Kilyos'a kadar uzanış kendisine pek neşeli ve düzgün bir dille yazllmış bir seyahatname ilham etmiş ve bu seyahatnameyi okuduktan sonra babam gülerek ... ${ }^{37}$

Örik, Nermi Bey'in hayatına dair aldığı notlarında Nermi Bey'in bu süreçte nerede kaldığını, nasıl geçindiğini kimsenin bilmediğini de ifade etmektedir. Bununla birlikte bekâr olduğu için hem Mâbeyn mütercimliğinden hem de Harbiyedeki muallimlik vazifesinden aldığı paralarla bir servet yaptı̆̆ hakkında söylentiler olduğunu dile getirmektedir. Lakin Balkan Harbi'nden sonra o dönem babasının tahrirat müdürlüğüne yeni tayin olan bir zatın tesadüfen Nermi Bey'i meşhur Tokatlıyan Oteli'nin önünde beklerken görmesi onu tanıyanların bu konudaki fikirlerini değiştirmiştir. Örik, Nermi Bey'in işsiz kaldığ 1 bu dönemde günde birkaç lira kazanmak için Tokatlıyan Oteli'nin kapıcısı vasıtasıyla otelde konaklayan ecnebilere tercümanlık yapmaya gittiğini bizatihi kendisinde işitmiş, Nermi Bey'in otelin içerisine kalabalık etmesin diye alınmadığını öğrendiklerinde ailecek üzüldüklerini ve artık Nermi Bey'in cimriliğinin onda bir hastalık hâline geldiğine kanaat ettiklerini

35 Taha Toros Arşivi, Dosya No:34, "http://earsiv.sehir.edu.tr:8080/xmlui/ handle/ 11498/38691."

36 Nahid Sırrı Örik, Abdülhamit Düşerken, Sander Yayınları, İstanbul 1976, s. 120-132'den aktaran Kırmızı, a.g.m., s.347.

37 Taha Toros Arşivi, Dosya No:34, "http://earsiv.sehir.edu.tr:8080/xmlui/ handle/ 11498/38691." 
belirtmiştir ${ }^{38}$.

Örik' in Nermi Bey'in cimriliği üzerinde 1srarla durması dikkat çekicidir ve anlaşıldığına göre Nermi Bey’in kazandığı paraları ne yaptığı onu tanıyanlar nazarında âdeta bir gizeme dönüşmüştür. Aslında Örik'in ortaya koyduğu veriler yani Nermi Bey'in Sultan II. Abdülhamid döneminde üstlendiği görevlerden elde ettiği gelirler, bekâr olması, mazuliyet maaşı alması gibi hususlar Nermi Bey'in cimriliği hususunda onu haklı çıkarır niteliktedir. Ama İstanbul gibi bir şehirde bekâr birinin hele ki de dolgun maaşı ıir bürokratın parayı harcayacak bir yerler bulması zor olmasa gerektir. Kaldı ki bu hususta arşivde yer alan bir hadise Nermi Bey'in biraz eğlenmeyi seven birisi olduğunu göstermektedir. Şöyle ki Nermi Bey bir cuma akşamı Harbiyeden çıkıp Hacı Osman (?) sokağında kiralık olarak ikamet ettiği evine gitmiş ve saat bir sularında Şişli' deki Gülistan gazinosuna gitmek için tekrar evinden ayrılmıştı. Gazinoya yaklaşık elli adım kala aralarında beş altı adım mesafe bulunan iki fesli şahıs Nermi Bey'in üzerine çullanmış ve "Sesini çıkarma şimdi seni öldürürüz !" diye tehdit etmişlerdi ki Nermi Bey bir şekilde feryat edip sesini etrafa duyurunca söz konusu şahıslar Nermi Bey'i kaburga kemiği yakınından bıçaklamışlar ve sonra ellerindeki tabancayla havaya ateş ederek kaçmışlard1 ${ }^{39}$. Bu adli vaka çerçevesinde başlatılan soruşturmadan ne sonuç çıktığı meçhuldür. Lakin Ahmed Nermi Bey’in Gülistan gazinosunun daha doğrusu birahanesinin müdavimlerinden olduğu anlaşılmaktadır.

Nahid Sırrı Örik'in Ahmed Nermi Bey’le alakalı kaleme aldığı notları 1. Dünya Savaşı öncesinde son bulmuştur. Nermi Bey savaş yıllarında İstanbul'da kalmıştır. Zira arşiv kayıtlarından Nermi Bey'in bir ara ücret karşılığ 1 Erkân-1 Harbiye-i Umumiye İstihbarat Şubesi için tercümanlık yaptığ 1 anlaşılmaktadır. Hatta 6 Eylül 1921 tarihli bir belgeden bizzat Harbiye Nazırı Ziya Paşa tarafından, yabancı ülke temsilcileriyle görüşmelerin yoğun bir şekilde devam etmesi nedeniyle, Rusça ve Fransızcayı iyi bilen Ahmed Nermi Bey’in ücret karşılığg görevine devam etmesiyle ilgili Sadarete bir yazı dahi gönderilmişti ${ }^{40}$.

Ahmed Nermi Bey, Kurtuluş Savaşı yıllarında İstanbul'u terk etmiş ve Ankara Erkân-1 Harbiye-i Umûmiye Riyasetine başvurarak kendisine münasip bir iş verilmesini istemişti. Belirtmek gerekir ki o dönem başta Mustafa Kemal Paşa olmak üzere Cumhuriyetin kurucu kadrosunda yer alan askerlerin Harbiyedeki eğitimleri sırasında Nermi Bey’den ders almış olmaları veyahut tanışıklarının bulunması kuvvetle muhtemeldir. Erkân-1 Harbiye Riyaseti, Nermi Bey’in durumunu Hariciye Vekâletine yazmış fakat Nermi Bey için Hariciye Vekâletinde münhal bir kadro bulunamamıştı. Bunun üzerine Nermi Bey’in askeri okullardan birinde istihdamı düşünülmüş ve bu durum Müdafaa-i Milliye Vekâletine yazılmıştı. Nihayet yapılan yazışmalar sonrasında Mekâtib-i Askeriye Müfettişliğinden Sarıkamış Askeri İdadisinde bir Fransızca muallimi kadrosunun boş bulunduğuna dair haber gelmişti. Lakin üç ayı aşan bu yazışmalar esnasında Nermi Bey’in açlıktan intihar ettiği öğrenilmişti ${ }^{41}$.

$\mathrm{Bu}$ intiharı öğrenen İcra Vekilleri Heyeti Reisi yani Gazi Mustafa Kemal Paşa oldukça müteessir olmuş ve Kurtuluş Savaşı'nın onca hengâmesi arasında Nermi Bey'in iş talebinin neden geç karşılık bulduğuna dair ilgili birimlere bir yazı göndermiş, bir daha benzer hadiselerin

38 Taha Toros Arşivi, Dosya No:34, “http://earsiv.sehir.edu.tr:8080/xmlui/ handle/ 11498/38691.”

39 BOA, Y. PRK. ASK, 60/44, 10 Şaban 1307 [1 Nisan 1890].

40 BOA, BEO, 4692 / 351892, 14 Muharrem 1340 [17 Eylül 1921]

41 BCA, Muamelat Genel Müdürlüğü, 45/ 291/ 17, 29.05.1923. 
yaşanmaması için gerekli tedbirlerin alınmasını istemişti. Bu yazının içeriği şu şekildeydi: 302 senesinde Mülkiye-i Şahaneden neşetle 23 sene Mekteb-i Harbiye Rusça muallimliğinde ve mütarekeden sonra da mülga İstanbul Erkân-ı Harbiye-i Umûmiye İstihbarat Şubesi Fransizca mütercimliğinde istihdam edilmiş olan Mâbeyn mütercimliğinden mütekâid ve son günlerinde açlıktan sulben intihar eden Ahmed Nermi Efendi'nin Hariciye kadrosu dâhilinde tevzîfi için vekâlet-i aliyyeleri nezdinde teşebbüsâtta bulunulduğu Erkân-ı Harbiye-i Umûmiye riyasetinin 26 14/39 tarihli ve 1447 numerolu tahrirâtında bilidirilmektedir. Müteveffâ-yı mûmâ-ileyh hakkında vekâlet-i aliyyelerince ne gibi muamele icra kılınmış olduğunun serian işarını ve bu gibi hidemât-ı meşkûreleri mesbûk bulunan zevâtın son demm-i hayatlarında zaruret ve sefalete düşmemeleri için müracaat vuku buldukça haklarında yapılacak muamelenin sürat-i mümküne ile intâcını bilhassa rica ederim efendim ${ }^{42}$.

\section{Sonuç}

Ahmed Nermi Bey'in hayatı aslında hüzünlü bir göç hikâyesidir. Nermi Bey'in Kazan'da başlayan hayatı ailesiyle birlikte İstanbul'a göç etmesiyle değişmiştir. Mülkiyedeki eğitimi, sonrasında Harbiyedeki muallimliği onu saraya yakınlaştırmış, yıllarca Sultan II. Abdülhamid'in Mâbeyninde çalışmış fakat onca hizmetine karşın onu tanıyanların ifadesiyle iddiasız, pısırık ruh hâli ve de karizmasının olmayışı nedeniyle bürokraside daha iyi bir konuma gelememiştir. Belirtmek gerekir ki Nermi Bey'in kariyerini ilerletmekle ilgili girişimleri olmuş, evlilik ve akrabalık yoluyla Babıali'deki nepotizm zincirine dâhil olmayı denemişse de kişiliği ve karakteriyle ilgili diğer etkenler yanı sıra Örik' in ifadesiyle "nasıl bir aileden geldiği meçhul" bir muhacir olması nedeniyle başarılı olamamıştır. Sultan II. Abdülhamid tahttan indirilince Nermi Bey çok zorlu bir hayata başlamış, bir devr-i sâbık memuru olarak yeni iktidardan iş istemektense otel önlerinde tercümanlık yapmayı göze alıp hayatını devam ettirmeyi tercih etmiştir. Nermi Bey, I. Dünya Savaşı yıllarında ücreti mukabili Erkân-1 Harbiye için bir süre mütercimlik yapmış, Kurtuluş Savaşı sırasında içinde bulunduğu sıkıntılı durumdan çıkış umuduyla üyelerinin çoğu eski öğrencisi olan Ankara Hükûmetinden bir iş talep etmiş fakat beklediği cevap gecikince intihar etmiş, Türk siyasetinde sıkça görülen tabiri caizse devr-i sâbık yaratma alışkanlığının kurbanı olmuştur.

\section{Kaynakça}

\section{Arşiv Kaynakları}

\section{Cumhurbaşkanlığı Osmanlı Arşivi (BOA)}

Defterler

Dâhiliye Nezareti Sicill-i Ahvâl Defterleri Fihristi Defter No: 47,71.

Belgeler

Babiali Evrak Odas1, 4692/351892.

Fotoğraflar, 557.

Hariciye Tahrirat, 193/90 
İrade Dâhiliye, 1019/80358

İrade Taltifât, 17 / 26

Y1ldız Perakende Evrak1 Arzuhal Jurnal, 22/66, 22/53, 26/77

Y1ldız Perakende Evrakı Askeri Maruzat, 60/44.

Cumhurbaşkanlığ 1 Cumhuriyet Arşivi (BCA)

Muamelat Genel Müdürlüğü, 45/ 291/ 17.

Gazeteler

Tanin, Hakkı Tarık Us Koleksiyonu, Yer No:0024.

\section{Hatıralar, Araştırma ve İncelemeler}

Balcı, Sezai, Babıâli Tercüme Odası, Libra Yayınları, İstanbul 2018.

Gökgöz, Saime Selenga, "II. Abdülhamid'e Takdim Edilen Bir Arz-1 Hâl: 'Kugu Sigorta' ve İslam Halifesi”, Kebikeç, (26), 2008, ss. 63-96.

Karabekir, Kazım, Türkiye'de ve Türk Ordusunda Almanlar, yay. haz. Orhan Hülagü-Ömer Hakan Özalp, Emre Yayınları, İstanbul 2001.

Kılınç Ocaklı, Arzu, “XIX. Yüzyılda İdil-Ural Bölgesinden Anadolu’ya Göçler”, Türkler, XIII, Yeni Türkiye Yayınları, Ankara 2002, ss. 896-906.

Kırmızı, Abdülhamit, "Meşrutiyette İstibdat Kadroları: 1908 İhtilali’nin Bürokraside Tasfiye ve İkame Kabiliyeti”, 100. Yllında Jöntürk Devrimi, ed. Sina Akşin-Sarp Balcı-Barış Ünlü, Türkiye İş Bankası Kültür Yayınları, İstanbul 2010, ss. 333-357.

Mehmed Esad, Mir'ât-ı Mekteb-i Harbiye, Artin Asaduryan Matbaası, İstanbul H 1310.

Örik, Nahid Sırrı, Abdülhamit Düşerken, Sander Yayınları, İstanbul 1976.

Özkan, Asaf, II. Meşrutiyet'ten Cumhuriyete Askeri ve Mülki Bürokraside Tasfiyeler, Askeri ve Mülki Heyet-i Mahsusalar, Atatürk Araştırma Merkezi Yayınları, Ankara 2014.

Pakalın, Mehmet Zeki, Osmanlı Tarih Deyimleri ve Terimleri Sözlüğ̈̈, III, Milli Eğitim Basımevi, İstanbul 1972.

Pirenne, Jacques, Büyük Dünya Tarihi, III, çev. Nihat Önol, Meydan Gazetesi Yayınları, İstanbul 1972.

Saydam, Abdullah, Kırım ve Kafkasya Göçleri (1856-1876), Türk Tarih Kurumu Yayınları, Ankara 1997.

Şirin, İbrahim, "Gazete, Kitap, Tiyatro Karşısında İmajını Korumaya Çalışan Sultan ve Maiyeti: Sultan II. Abdülhamid ve Ahmed Nermi”. Uluslararası Klbrıs Üniversitesi Folklor/ Edebiyat Dergisi, 17 (66), 2011, ss. 39-55.

Wallach, Jehuda L. , Bir Askeri Yardımın Anatomisi, çev. Fahri Çeliker, Genelkurmay Başkanlığı Yayınları, Ankara 1977.

Yergök, Ziya, Tuğgeneral Ziya Yergök'ün Anıları, Harbiye'den Dersime (1890-1914), yay. haz. Sami Önal, Remzi Kitabevi, İstanbul 2006. 


\section{İnternet Kaynakları}

Cin, Halil, "Hasan Sırrı Örikağasızâde”, Türk Edebiyatı İsimler Sözlüğ̈̈, http://teis.yesevi. edu.tr/madde-detay/hasan-sirri-orikagasi zade, e.t. 18.08.2020.

http://www.servetifunundergisi.com/rusya-salib-i-ahmer-heyeti-refakatlerine-memur-hmetnermi-efendi/, e.t. 18.08.2020.

Taha Toros Arşivi, Dosya No:34, http://earsiv.sehir.edu.tr:8080/xmlui/ handle/ 11498/38691, e.t. 18.08.2020. 